\title{
A child with a rare genetic disease - Noonan syndrome
}

\author{
Patryk Siwik', Anna Janas ${ }^{1}$ \\ 1 Department of Oral Surgery, Medical University of Lodz, Poland
}

Siwik P, Janas A. A child with a rare genetic disease - Noonan syndrome. J Pre-Clin Clin Res. 2015; 9(1): 87-88. doi: 10.5604/18982395.1157584

\begin{abstract}
Noonan syndrome is a congenital developmental disorder characterized by short stature, facial dysmorphia, congenital heart defects and skeletal anomalies, with as estimated incidence of between one per 1000 and one per 2500 live births. The aim of our study is to present a case of dental surgical treatment of a child with such disorder. It is widely reported that children with mental disabilities receive less dental and medical care than their nondisabled counterparts. Because of this problem, it seems justified to describe the procedures of treating such children with dental issues, basing on a case of a girl with Noonan Syndrome.
\end{abstract}

\section{Key words}

Noonan Syndrome, genetic diseases, surgical treatment

\section{INTRODUCTION}

Noonan syndrome is a genetic disease caused by autosomaldominating inheritance, characterized by defects in: short stature, facial skeleton, congenital heart defects, cryptorchid, intellectual disability and usually mild haematological malformations [1]. The cause of the syndrome is mutation in the PTPN 11, KRAS, SOS 1 gene and the occurrence of the disease is 1 per 1,000-2,500 live births, which makes the Noonana syndrome the most common genetic disease [2]. Kobyliński, a medical student from Dorpata in Estonia was the first to describe a patient with this phenotype in the Archiv für Anthropologie in 1883. However, it was not until 1968 that Jacqueline Anne Noonan, an American pediatrician and pediatric cardiologist, first described the disorder as a new syndrome [3].

The characteristics of the newborn baby with the Noonan syndrome are hypertelorism wide-set eyes, downwardslanting palpebral fissures, ptosis, low-set ears with thick helix of the ear, and a short and wide neck. There are also malformations in body structure, such as short stature, caused by growth hormone deficiency. In males, the average height varies between $161-162.5 \mathrm{~cm}$, while in females $-150-152.7 \mathrm{~cm}$ [4]. With age, the dysmorphic features of the facial skeleton change: drooping of the eyelids, light blue iris, small upturned nose, short neck with low hairline at the nape of the neck, broad forehead and curly hair. Most of the patients suffer from a congenital heart defect which is found in 55\% of patients, caused by stenosis of the pulmonary artery or hypertrophic cardiomyopathy. Prominence and depression of the breast bone (pectus carinatum/pectus excavatum), scoliosis and spine fusion are also characteristic of this disease.

There are also others symptoms, such as cryptorchidism (undescended testicles), subnormal maturation, combined coagulation defects, and prolonged activated partial thromboplastin time caused by partial deficiency of factors XI,VIII and XII. Patients with Noonan syndrome also have hepatomegaly and splenomegaly and disorders in the lymphatic system. An important factor which increases risk

Address for correspondence: Anna Janas, Department of Oral Surgery, Medical University of Lodz, 92-213 Lodz, 251 Pomorska St., Poland E-mail: anna.janas@umed.lodz.pl

Received: 14 September 2014; accepted: 14 October 2014 of occurrence of the disease is the age of the parents: the older they are the bigger the risk. Less characteristic are hypoacusia or deafness, cleft palate, peripheral neuropathy, hypothyroidism, and sometimes hyperthermia malignant. There are also problems with the eyes, primarily astigmatism, strabismus, myopia, and sometimes cleft iris $[4,5,6]$.

Objective. To describe a case of a child with Noonan syndrome from the perspective of an oral surgeon

\section{CASE REPORT}

A 6-year-old girl was referred to a cardiologist because of repeated inflammations of the mandible and crestal bone. A chart obtained from the parents also revealed information about mild mental retardation with impaired concentration.

The mother of child, who was 38-years-old when she gave birth to the patient, was in generally good health. Pregnancy was without complications; she did not drink alcohol nor take any drugs during pregnancy. Both parents were generally healthy and unrelated, and their older children were also healthy.

Extra oral examination showed low set ears, short neck, scoliosis, with weight smaller than normal, and also small hands and feet. Patients height was $131 \mathrm{~cm}$ and weight $26 \mathrm{~kg}$ [Fig. 1]. Intraoral examination showed a high arched palate,

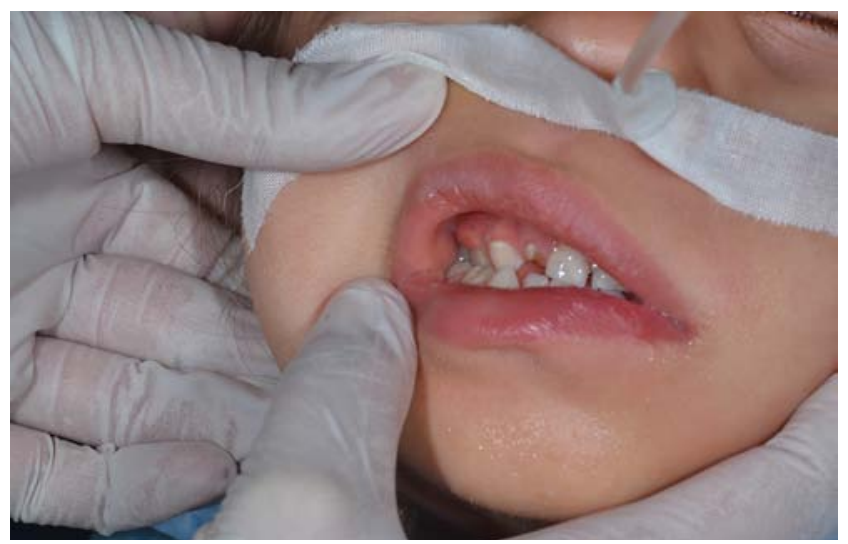

Figure 1. A child with Noonan Syndrome 
dental caries with inflammations in area of teeth 53 and 55, and an malocclusion, caused by insufficient development of the mandible.

The mother of the patient was presented with the plan of surgical treatment, and after obtaining her written consent, the extraction of teeth was carried out under general anaesthesia [Fig. 2]. The procedure was carried out without complications, after which the patient stayed in a recovery room where her vital signs were monitored. After achieving the stabilization of all the vitals, the patient was discharged from the hospital into the care of her family at home.

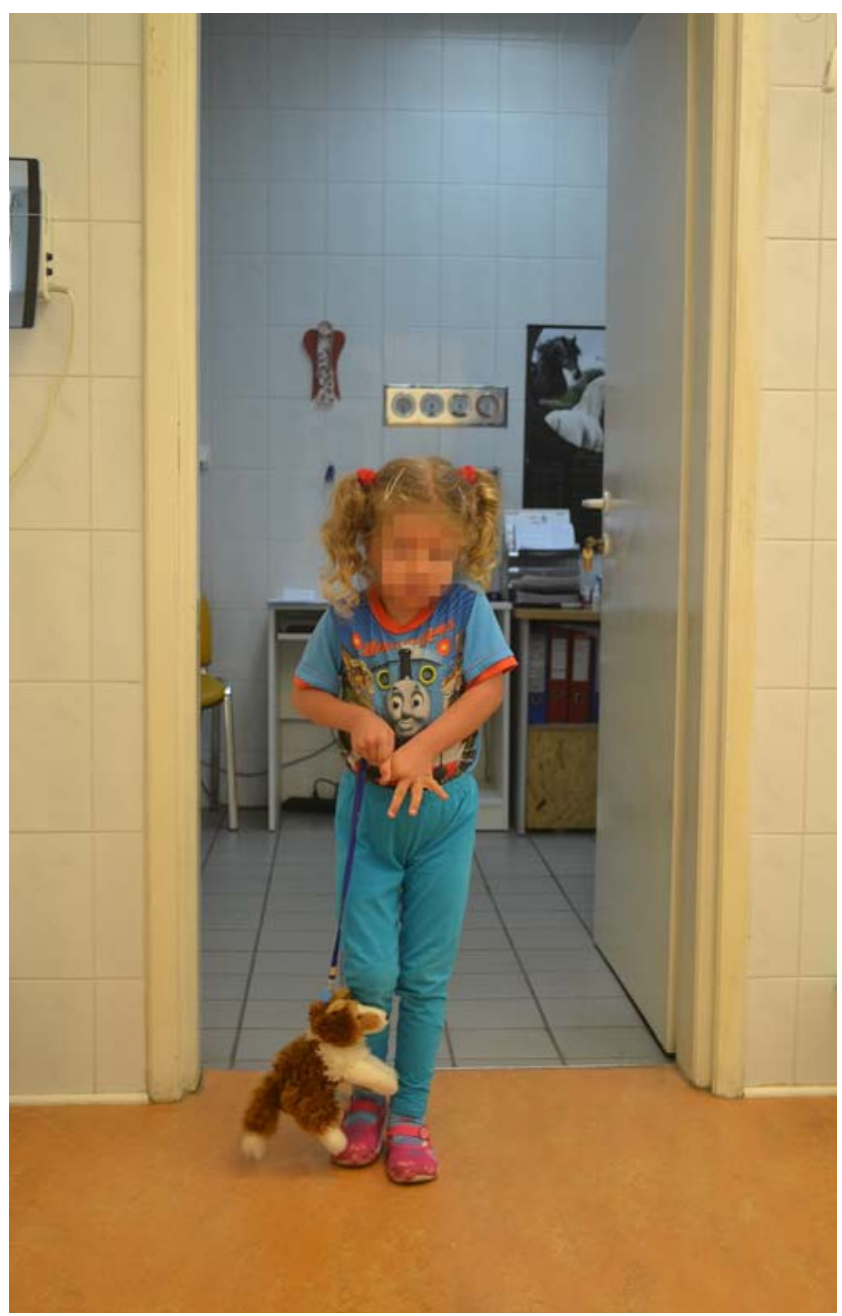

Figure 2. The girl treated in the procedures of 1-day surgery

\section{CONCLUSIONS}

Noonan syndrome is characterized by hypertelorism, proptosis, low set ears with thick helix, short, webbed neck, short stature and emotional disorders with intellectual disability. Regular features of this disease are light blue iris, small upturned nose, webbed neck with low hairline at the nape, broad forehead, curly light hair, all of which were confirmed in the presented case. The patients frequently have problems of a behavioral nature, vision defects and breathing disorders. The genes responsible for pigmentation occur on chromosome 12, which explains the fact that most of the patients with NS have a bright complexion, almost gray hair and light blue irises $[6,7]$.

In the first days of life, patient with NS have health problems and mental retardation and because of the rarity of the disease, its early diagnosis is problematic [8]. The symptoms of NS could also be confused with other rare genetic disorders, such as Costello syndrome, Turner syndrome (TS), Williams syndrome (WS), Aarskog-Scott syndrome (AAS), Baraitser-Winter syndrome (BWS), King-Denborough syndrome [KDS], Cardiofacuocutaneous syndrome (CFC) and Fetal alcohol syndrome (FAS). People affected by Noonan syndrome require multi-speciality treatment early on in first days of life, in most cases cardiovascular surgery is necessary. The time of diagnosis is decisive for the development of the child and has a beneficial effect on the special care and stimulation of psychomotor development [10].

Noonan syndrome is a multi-symptoms disease, differentiated in terms of clinical and dysmorphic features, and diagnosis of the disease is both difficult and timeconsuming.

Despite progress that was made in recent years, there are many issues that require additional research to explain the genotype-phenotype correlation.

Patients with NS are not willingly accepted and treated by dentists, which was confirmed in the presented case.

\section{REFERENCES}

1. Judith E. Allanson, Noonan Syndrome. Managment of Genetic Syndrome 2010 .

2. Soultanis KC, Payatakes AH, Chouliaras VT, Mandellos GC, Pyrovolou NE, Pliarchopoulou FM, Soucacos PN. Rare causes of scoliosis and spine deformity: experience and particular features. Scoliosis 2007; 2: 15 .

3. Kelnar CJ. Growth hormone therapy for syndromic disorders. Clin Endocrinol (Oxford). 2003; 59(1): 12-21.

4. Yoshida R, Hasegawa T, Hasegawa Y, Nagai T, Kinoshita E, Tanaka Y, Kanegane H, Ohyama K, Onishi T, Hanew K, Okuyama T, Horikawa R, Tanaka T, Ogata T. Protein-tyrosine phosphatase, nonreceptor type 11 mutation analysis and clinical assessment in 45 patients with Noonan syndrome. J Clin Endocrinol Metab. 2004; 89(7): 3359-3364.

5. Tartaglia M, Kalidas K, Shaw A, Song X, Musat DL, van der Burgt I, Brunner HG, Bertola DR, Crosby A, Ion A, Kucherlapati RS, Jeffery S, Patton MA, Gelb BD. PTPN11 mutations in Noonan syndrome: molecular spectrum, genotype-phenotype correlation, and phenotypic heterogeneity. Am J Hum Genet. 2002; 70(6): 1555-1563.

6. Hilczer M, Smyczyńska J, Kaniewska D, Stawerska R, Lewiński A. Wielkość przysadki i wydzielanie hormonu wzrostu u dzieci z niedoborem wzrostu; zalezność pomiedzy wielkością przysadki a odpowiedzią na hormon wzrostu w pierwszym roku leczeniau dzieci z niedoborem hormonu wzrostu. Endokrynol Pediatr. 2003; 3: 9-19 (in Polish).

7.Lewiński A, Hilczer M, Pniewska-Siark B, Smyczyńska J, Stawerska R. Ogólnopolski program leczenia niedoboru wzrostu u ludzi dorosłych. Endokrynol Pol. 2000; 51: 645-691 (in Polish).

8. Baroncelli GI, Bertelloni S, Ceccareli C, Saggese G. Effect of growth hormone treatment on final height, phosphate metabolism, and bone mineral density in children with X-linked hypophosphatemic rickets. J Pediatr. 2001; 138: 236-243.

9. Respondek-Liberska M. Sonograficzne markery zespołów genetycznych. Przegląd Chirurgii Dziecięcej 2009; 4(2-3): 29-41 (in Polish).

10. Janas A, Osica P, Siwik P, Grzesiak-Janas G. Dziecko z rzadką chorobą genetyczną - zespołem Cornelii de Lange. MS. 2013; 3: 72-74 (in Polish). 